\title{
Assessment of Helicoverpa armigera (Hubner) Adult Population in Chickpea using Weather Based Indices
}

\author{
D. Sagar, Suresh M. Nebapure, Subhash Chander
}

10.18805/LR-4367

\begin{abstract}
Background: Chickpea is the second most important pulse crop grown globally, it is damaged by over 50 insect species in different parts of the world, of which gram pod borer, Helicoverpa armigera (Hubner) poses serious threat to production. Temperature is one of the important abiotic factor influencing the growth and development of an organism, degree day (DD) models are very useful in pest predictions as development of insects and plants is temperature-dependent and can predict the biological phenomenon with greater accuracy.

Methods: $H$. armigera adult population at different chickpea phenological stages viz., from emergence to maturity stage was assessed using the weather based indices viz., growing degree days (GDD) and heliothermal units (HTU) during rabi 2015-16, 2016-17 and 2017-18 at ICAR- Indian Agricultural Research Institute, New Delhi.

Results: At different chickpea phenological stages the pest population varied from 0 to $66.3,0$ to 256 and 0 to 124 with respective cumulative population of 148, 555 and 167 male moth catches during three consecutive seasons. Among different phenological stages, highest population was recorded during both pod formation and crop maturity stage during 2015-16 and 2017-18, while in 2016-17 it was maximum during 50 per cent flowering and maturity stage. Among the three seasons, the GDD and cumulative male moth trap catches were found to be highest during 2016-17. The relationship of GDD and HTU with $H$. armigera was analysed through linear regression and they accounted for 64 and 71 per cent variation respectively in pest population across the seasons. The weather based indices viz., GDD and HTU may thus be useful for predicting $H$. armigera adult population at different chickpea phenological stages.
\end{abstract}

Key words: Chickpea, Growing degree days, Helicoverpa armigera, Heliothermal units, Phenophases, Weather indices.

\section{INTRODUCTION}

Chickpea (Cicer arietinum L.), known as king of pulses is the second most important pulse crop grown globally on an area of 14 million ha across 55 countries and plays an important role in human nutrition. India is the largest producer of chickpea with a share of about $70 \%$ in area and $67 \%$ in production in the world (Dixit et al., 2017). In India, the area under chickpea was 9.63 million ha with a production of 9.38 million tonnes and productivity of 974 $\mathrm{kg} /$ ha during rabi 2016-17 (Anonymous, 2018).Chickpea is damaged by over 50 insect species in different parts of the world, of which gram pod borer, Helicoverpa armigera (Hubner) poses serious threat to chickpea production causing yield loss up to 80 per cent. The management of this pest is very difficult due to its mobility, quick adaptation to various agro-ecologies, high reproductive rate, overlapping generations, short generation duration, polyphagy and high levels of resistance to conventional insecticides (Sarode, 1999; Kranthi et al., 2002; Parde et al., 2012; Fitt, 1989).

Temperature is one of the important abiotic factor influencing the growth and development of an organism and has been used in development of prediction models along with other weather factors like humidity, sunshine hours, rainfall and wind speed. Degree-day (DD) based models being universal in nature are very useful in pest predictions as development of insects and plants is temperature-
Division of Entomology, ICAR-Indian Agricultural Research Institute, New Delhi-110 012, India.

Corresponding Author: D. Sagar, Division of Entomology, ICARIndian Agricultural Research Institute, New Delhi-110 012, India. Email: garuda344@gmail.com

How to cite this article: Sagar, D., Nebapure, S.M. and Chander, S., Assessment of Helicoverpa armigera (Hubner) Adult Population in Chickpea using Weather Based Indices. Legume Research. ():

Submitted: 04-03-2020 Accepted:22-05-2020 Published:

dependent and can predict the biological phenomenon with greater accuracy (Mussey and Potter, 1997). The growing degree day, is a heat index a measure of heat accumulation which can be used to predict plant as well as pest development. In an agricultural ecosystem the determination of GDD is vital not only for the crops (Tripathi et al., 2009; Singh and Singh, 2014) but also for the insect pests (Chattopadhyay et al., 2005; Hamed and Nadeem, 2010) which are dependent on phenology of the crop (Sridhar and Reddy, 2013;Herms, 2004). Day-degree models have been used to predict the onset of fight activity and pheromone trap catches of lepidopterans and also be used for forecasting the emergence and timing of insecticide application (Ahmed and Khalique, 2002).With these models, it is also possible to predict the life events of the insect pests 
for the timely decision in pest management (Kulhanek, 2009; Herbert et al., 1988). Besides, sunshine hours and day length based prediction models may also be used to assess the gram pod borer adult population. In this context, a study was conducted to explore the use of weather based indices viz., growing degree days (GDD) and heliothermal units (HTU) of chickpea for assessing the $H$. armigera adult population in chickpea.

\section{MATERIALS AND METHODS}

Adult population of $H$. armigera at different crop phenological stages was assessed using the GDD and HTU of chickpea during rabi 2015-16, 2016-17 and 2017-18 at ICAR- Indian Agricultural Research Institute, New Delhi $\left(28.08^{\circ} \mathrm{N}, 77.12^{\circ}\right.$ $\mathrm{E}, 228.61 \mathrm{~m})$. Data on the incidence of gram pod borer, $H$. armigera was recorded in accordance with Sagar et al. (2017), by using Fero-T traps @ 5 traps/ha with Helilure, procured from Pest Control India (PCl) Pvt. Ltd. and lures were replaced with new ones after every 20 days. $H$. armigera adult trap catches were recorded every standard meteorological week (SMW) and expressed as mean number of male moths/trap/week and were square root transformed before subjecting them to regression analysis. The different phenological stages of chickpea were considered according to Tripathi et al. (2009). Weekly data of maximum and minimum temperature, bright sunshine hours and rainfall were obtained from the Agricultural Physics Division, ICAR-IARI, New Delhi (Fig 2). Growing degree days and heliothermal units were calculated as follows:
Growing degree days $(G D D)=\Sigma\left(T_{\text {Max }}+T_{\text {Min }}\right) / 2-T_{\text {Base }}$ Where,

$T_{\text {Max }}$ and $T_{\text {min }}$ are the maximum and minimum temperatures $\left({ }^{\circ} \mathrm{C}\right)$ of the day and $\mathrm{T}_{\text {Base }}$ is base temperature which is taken as $5^{\circ} \mathrm{C}$ for chickpea (Silawat et al., 2015).

Heliothermal units $(\mathrm{HTU})=$

$$
\text { GDD } \times \text { actual bright sunshine hour }(n)
$$

Growing degree days and heliothermal units were computed on daily basis from $20^{\text {th }}$ November to mid of April month. Twentieth November was considered as base for each year as chickpea is sown majorly during the third week of November in northern parts of India. Linear regression analysis was carried out between each of GDD and HTU of chickpea with $H$. armigera adult population at different crop phenophases for all three years using MS Excel. The GDD and cumulative rainfall was also calculated during 51-10 SMW and they were compared with the cumulative trap catches and peak population of $H$. armigera during 51-15 SMW in each year.

\section{RESULTS AND DISCUSSION Helicoverpa armigera population}

Adult population of $H$. armigera during three seasons in chickpea (rabi) when plotted against the SMW (Fig 1), evinced that the population initiation took place from $6^{\text {th }} \mathrm{SMW}$ and reached the peak during $12^{\text {th }}$ and $15^{\text {th }}$ SMW with 37.3 and 62 male moths/trap/week during 2015-16 and 2017-

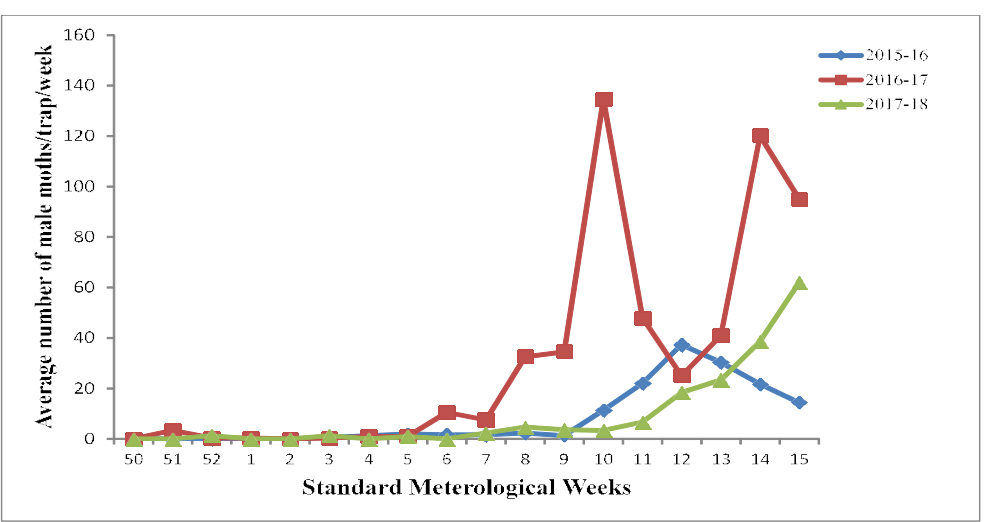

Fig 1: Pheromone trap catches of Helicoverpa armigera in chickpea during 2015-16 to 2017-18.

Table 1: Population dynamics of Helicoverpa armigera and thermal indices of chickpea at different phenological stages during 2015-16 to 2017-18.

\begin{tabular}{|c|c|c|c|c|c|c|c|c|c|c|}
\hline \multirow[t]{2}{*}{$\begin{array}{l}\text { Phenological } \\
\text { stage }\end{array}$} & \multirow[t]{2}{*}{$\begin{array}{l}\text { Days } \\
\text { taken }\end{array}$} & \multicolumn{3}{|c|}{$\begin{array}{c}\text { Helicoverpa armigera } \\
\text { trap catches* }\end{array}$} & \multicolumn{3}{|c|}{$\begin{array}{l}\text { Growing degree } \\
\text { days }\left({ }^{\circ} \mathrm{Cd}\right)\end{array}$} & \multicolumn{3}{|c|}{ Heliothermal units } \\
\hline & & $2015-16$ & $2016-17$ & 2017-18 & $2015-16$ & $2016-17$ & 2017-18 & $2015-16$ & $2016-17$ & 2017-18 \\
\hline Emergence & 8 & $0(0.70)$ & $0(0.70)$ & $0(0.70)$ & 104.9 & 111.2 & 84.3 & 514.0 & 644.96 & 531.09 \\
\hline Vegetative & 96 & 9.64 (3.18) & $56.82(7.57)$ & 10.65 (3.33) & 946.1 & 991.2 & 893.9 & 3311.3 & 4956 & 5005.84 \\
\hline $50 \%$ flowering & 111 & 12.7 (3.63) & 169 (13.0) & $6.99(2.73)$ & 1175.5 & 1206.8 & 1110.6 & 6817.9 & 9654.4 & 7996.32 \\
\hline Pod formation & 126 & $59.3(7.73)$ & $73(8.57)$ & $25(5.04)$ & 1436.5 & 1437.1 & 1374.4 & 10773.7 & 11784.2 & 10995.2 \\
\hline Maturity & 146 & $66.3(8.17)$ & $256(16.0)$ & 124(11.15) & 1861.9 & 1897.8 & 1811.6 & 13778.1 & 16700.6 & 14855.1 \\
\hline Total population & & $148(12.18)$ & $555(23.56)$ & $167(12.94)$ & & & & & & \\
\hline
\end{tabular}

${ }^{*}$ Cumulative trap catches during that phenological stage; figures in parentheses are square root transformed. 

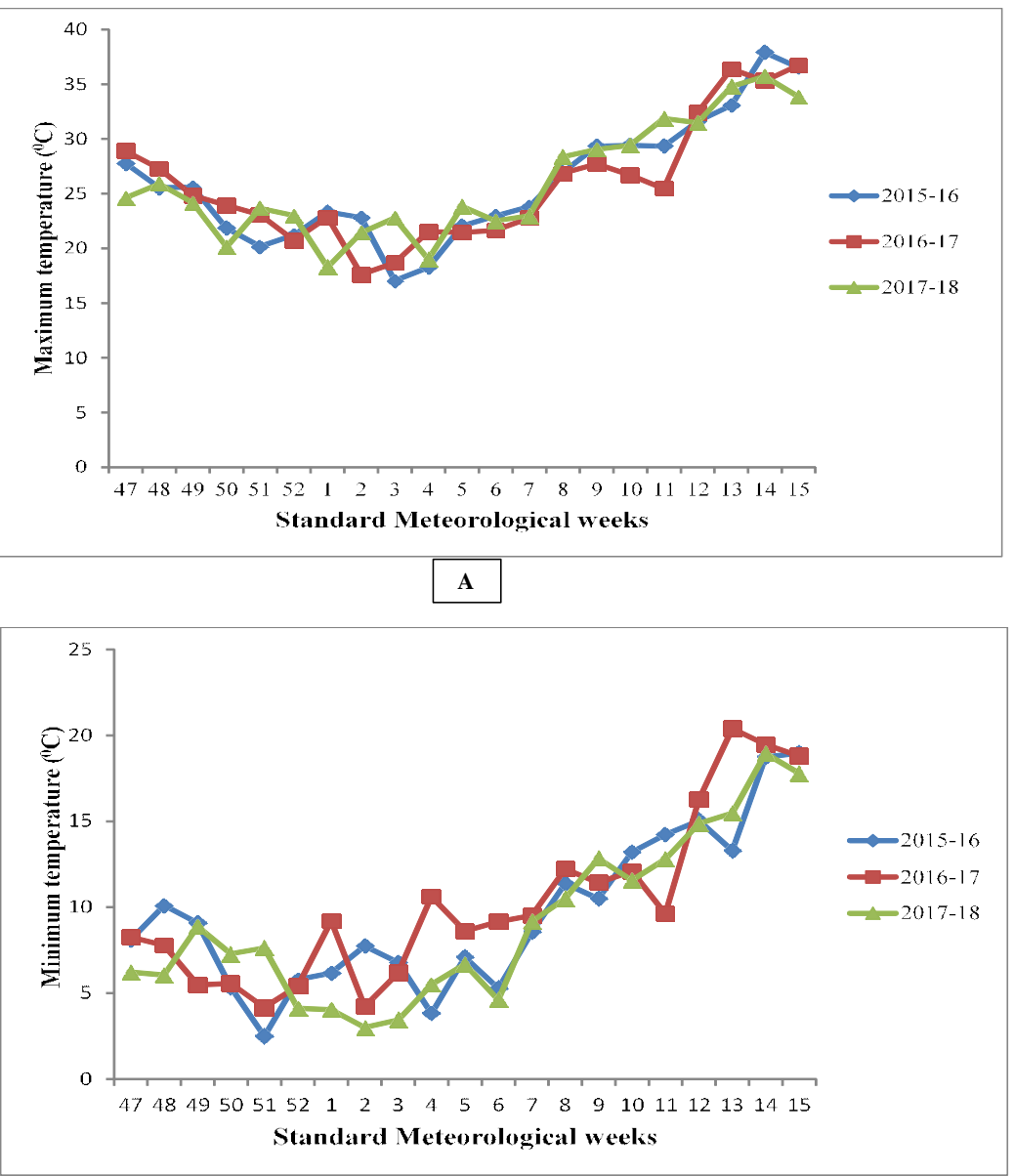

B

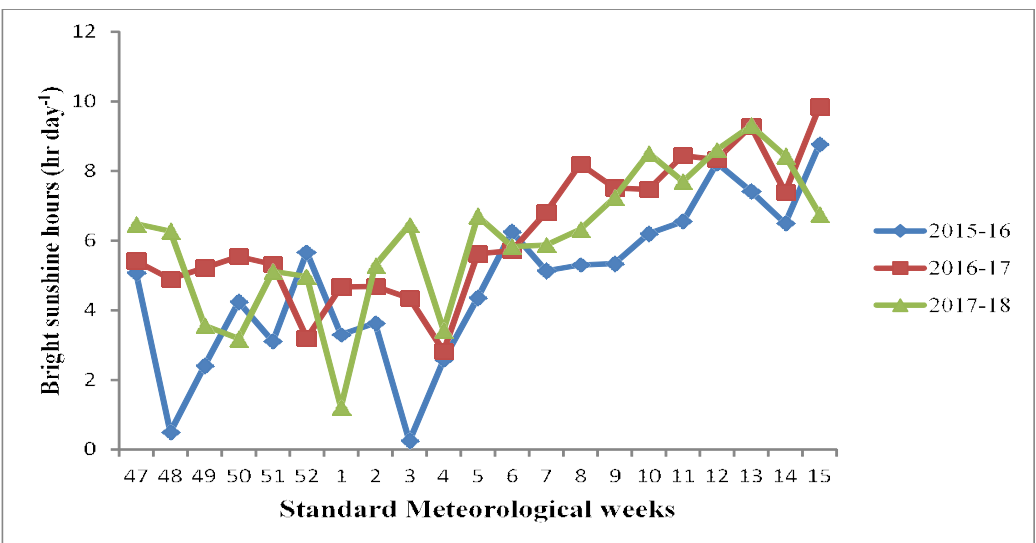

C

Fig 2: Dynamics of weather factors during the study period (2015-16 to 2017-18). A) Maximum temperature $\left({ }^{\circ} \mathrm{C}\right)$,

B) Minimum temperature $\left.\left({ }^{\circ} \mathrm{C}\right), \mathrm{C}\right)$ Bright sunshine hours $\left(\mathrm{hr}^{\mathrm{A}} \mathrm{day}^{-1}\right)$.

Table 2: Growing degree days, seasonal rainfall and population of Helicoverpa armigerain chickpea during 2015-16 to 2017-18.

\begin{tabular}{lcccr}
\hline Year & $\begin{array}{c}\text { Growing degree days } \\
\left({ }^{\circ} \mathrm{Cd}\right)(51-10 \text { SMW })\end{array}$ & $\begin{array}{c}\text { Rainfall }(\mathrm{mm}) \\
51-10 \text { SMW }\end{array}$ & $\begin{array}{c}\text { Cumulative trap } \\
\text { catches }(51-15 \text { SMW })\end{array}$ & $\begin{array}{c}\text { Peak } \\
\text { Population }\end{array}$ \\
\hline $2015-16$ & 888.9 & 8.0 & 148 & 37 \\
$2016-17$ & 905.26 & 79.2 & 555 & $135+120=255$ \\
$2017-18$ & 859.2 & 6.0 & 167 & 62 \\
\hline
\end{tabular}


18 , respectively, while in $2016-17$ the population reached the peak twice with 134.5 and 120 male moths/trap/week during $10^{\text {th }}$ and $14^{\text {th }}$ SMW, respectively.

At different phenological stages of chickpea viz., from emergence to maturity stage, the $H$. armigera population varied from 0 to $66.3,0$ to 256 and 0 to 124 with respective cumulative population of 148,555 and 167 male moth catches during rabi 2015-16, 2016-17 and 2017-18, respectively (Table 1 ). Among different phenological stages, highest population was recorded during both pod formation and crop maturity stage during 2015-16 and 2017-18, while it was maximum during 50 per cent flowering and maturity stage in 2016-17. It can be inferred from the results that maximum trap catches coincided with reproductive stage of the crop. Earlier also Kahrarian (2012) in Iran observed the peak activity of chickpea pod borer (Heliothis viriplaca) having coincided with $50 \%$ flowering stage of the crop.

Among three years, GDD $\left(905.26^{\circ} \mathrm{Cd}\right)$ and cumulative rainfall $(79.2 \mathrm{~mm})$ were highest during $2016-17$, which also had highest cumulative male moth trap catches during 5115 SMW (Table 2). It thus revealed that GDD and cumulative rainfall during 51-10 SMW had a direct relationship with the pest population buildup in chickpea.

\section{Growing degree days and heliothermal units}

The GDD of chickpea ranged between 84.3 to $1897.8^{\circ} \mathrm{Cd}$ that corresponded with germination to maturity stages of chickpea across the three years. From emergence to maturity stage, the GDD varied significantly with 104.9 to $1861.9,111.12$ to 1897.8 and 84.3 to $1811.6^{\circ} \mathrm{Cd}$ during rabi 2015-16, 2016-17 and 2017-18 respectively (Table 1). Among the three seasons the GDD was found to be highest during 2016-17, during which cumulative male moth trap catches were also found to be highest (555 trap catches). The heliothermal units of chickpea ranged from 514 to $13778.1,644.96$ to 16700.6 and 531.09 to 14855.1 during rabi 2015-16, 2016-17 and 2017-18 respectively with maximum heliothermal units during 2016-17. Earlier, The relationship between GDD and pest population and opined that the GDD of 1-10 SMW had direct relationship with population build-up of $H$. armigera during chickpea season (Anonymous, 2007).

Relationship between growing degree days and heliothermal units of chickpea with male moth catches of $\boldsymbol{H}$. armigera

The linear regression of the weather based indices with $H$.

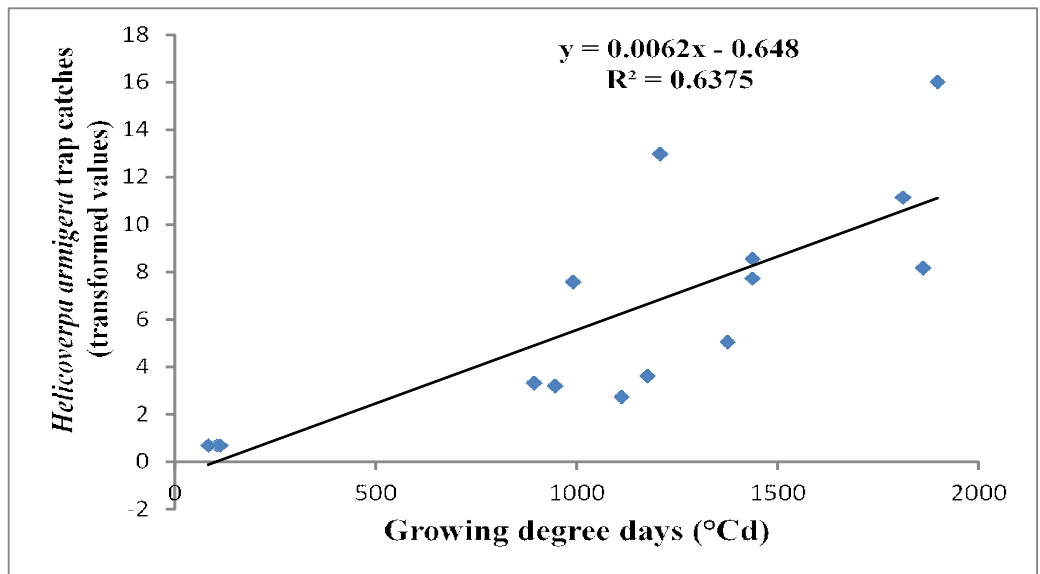

Fig 3: Relationship between growing degree days of chickpea and Helicoverpa armigera population.

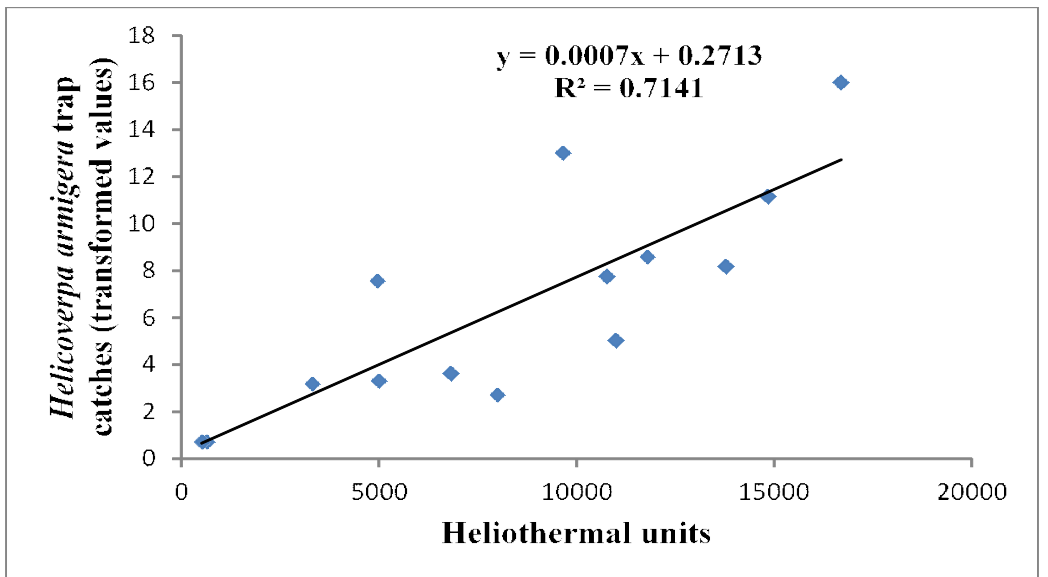

Fig 4: Relationship between heliothermal units of chickpea and Helicoverpa armigera population. 
armigera population depicted that the GDD $(H$. armigera population $\left.=0.0062 x-0.648, \mathrm{R}^{2}=0.637\right)$ and $\operatorname{HTU}(H$. armigera population $=0.0007 x+0.271, R^{2}=0.714$ ) explained 64 and 71 per cent variation, respectively in the pest population across the three seasons (Fig 3 and 4). Ahmed and Khalique (2002) developed the prediction models for $H$. armigera using degree-day accumulation method and predicted the start, peak and end of $H$. armigera trap catches in chickpea based on them. Mussey and Potter (1997) opined that plant phenological sequences could be used as reliable indicators for predicting insect activity from year to year with greater consistency compared to weather which exhibits tremendous variation.

\section{CONCLUSION}

In the present study the weather based indices viz., GDD and HTU could account for variation in $H$. armigera population across the seasons and can thus be used for predicting $H$. armigera population at different phenological stages of chickpea.

\section{ACKNOWLEDGEMENT}

With at most pleasure and sincerity, the authors thankfully acknowledge whole heartedly Dr. C. Bharadwaj, Dr. Venkatraman Hegde and Dr. Shailesh Tripathi, ICAR-IARI, New Delhi for their help to undertake this study and authors are also grateful to Head, Division of Entomology, ICARIARI, New Delhi for providing required support during these studies.

\section{REFERENCES}

Ahmed, K. and Khalique, F. (2002). Forecasting adult populations of Helicoverpa armigera on chickpea using pheromone trap. Pakistan Journal of Biological Sciences. 5: 83034.

Anonymous, (2007). Annual Report 2006-07, National Centre for Integrated Pest Management, LBS Building, Pusa Campus, New Delhi-110 012 India. Pp. 55-58.

Anonymous, (2018). Project Co-ordinator's Report 2017-18. All Indian Co-ordinated Research project on chickpea, ICARIndian Institute of Pulses Research. pp. 1-45.

Chattopadhyay, C., Agrawal, R., Kumar, A., Singh, Y.P., Roy, S.K., Khan, S.A., Bhar, L.M., et al. (2005). Forecasting of Lipaphis erysimi on oilseed Brassicas in India- A case study. Crop Protection. 24(12): 1042-1053.

Dixit, G.P., Sarvjreet Singh, Jayalakshmi, V., Srivastava A.K. and Gaur, P.M. (2017). Chickpea improvement - Accomplish-ments, challenges and strategies. National symposium on Pulses for Nutritional Security and Agricultural Sustain-ability, IIPR, Kanpur, pp.45.

Fitt, G.P. (1989). The ecology of Heliothis species in relation to agro-ecosystem. Annual Review of Entomology. 34: 17-52.

Hamed, M. and Nadeem, S. (2010). Forecasting of spotted bollworm (Earias vitella (Fab.)(Lepidoptera: Noctuidae) occurrence in cotton. Pakistan Journal of Zoology. 42(5): 575-580.

Herbert, D.A., Mack, T.P., Reed, R.B. and Getz, R. (1988). Degreeday maps for management of soybean insect pests in Alabama. pp.20.

Herms, D.A. (2004). Using degree-days and plant phenology to predict pest activity. In Tactic and tools for IPM, pp. 49-59.

Kahrarian, M. (2012). Studies of occurrence of pod borer Heliothis viriplaca in relation to the phenology of chickpea in rainfed chickpea fields in Kermanshah region of Iran. African Journal of Biotechnology. 11(9): 2190-2198.

Kranthi, K.R., Jadhav, D.R., Kranthi, S., Wanjari, R.R., Ali, S.S., Russel, D.A. (2002). Insecticide resistance in five major insect pests of cotton in India. Crop Protection. 21: 449460.

Kulhanek, A.L. (2009). User-friendly methods for timing integrated pest management strategies: An analysis of degree-day models and biological calendars (Doctoral dissertation, The Ohio State University).

Mussey, G.J. and. Potter, D.A. (1997). Phenological correlations between flowering plants and activity of urbanlandscape pests in Kentucky. Journal of Economic Entomology. 90: 1615-1627.

Parde, V.D., Sharma, H.C. and Kachole, M.S. (2012). Protease inhibitors in wild relatives of pigeonpea against the cotton bollworm/legume pod borer Helicoverpa armigera. American Journal of Plant Sciences. 3: 627-635.

Sagar, D., Nebapure, S.M and Chander, S. (2017). Development and validation of weather based prediction model for Helicoverpa armigera in chickpea. Journal of Agrometeoro-logy. 19(4): 328-333.

Sarode, S.V. (1999). Sustainable management of Helicoverpa armigera (Hubner). Pestology. 13(2): 279-284.

Silawat, S., Srivastava, A.K. and Agarwal, K.K. (2015). Characteri-zation of thermal environment for optimization of growth and yield in chickpea in Kymore plateau and Satpura hillsagroclimatic zone of Madhya Pradesh. Journal of Agricultural Physics. 15(1): 45-54.

Singh, M.P. and Singh, N.B. (2014). Thermal requirement of Indian mustard (Brassica juncea) at different phonological stages under late sown condition. Indian Journal of Plant Physiology. 19(3): 238-243.

Sridhar, V. and Reddy, P.V.R. (2013). Use of degree days and plant phenology: a reliable tool for predicting insect pest activity under climate change conditions. In: Climate-resilient Horticulture: Adaptation and Mitigation Strategies. Springer, India. pp. 287-294.

Tripathi, P., Singh, A. K. and Shabd, A. (2009). Growth and thermal unit of chickpea (Cicer arietinum L.) genotypes under variable weather conditions of Eastern Uttar Pradesh. Asian Journal of Environmental Science. 3(2): 164-168. 